University of Chicago Law School

Chicago Unbound

Journal Articles

Faculty Scholarship

2004

\title{
Mutual Assent Versus Gradual Ascent: The Debate Over the Right to Retract
}

Omri Ben-Shahar

Follow this and additional works at: https://chicagounbound.uchicago.edu/journal_articles

Part of the Law Commons

\section{Recommended Citation}

Omri Ben-Shahar, Response, "Mutual Assent Versus Gradual Ascent: The Debate Over the Right to Retract", 152 University of Pennsylvania Law Review 1947 (2004).

This Article is brought to you for free and open access by the Faculty Scholarship at Chicago Unbound. It has been accepted for inclusion in Journal Articles by an authorized administrator of Chicago Unbound. For more information, please contact unbound@law.uchicago.edu. 


\section{RESPONSE}

\section{MUTUAL ASSENT VERSUS GRADUAL ASCENT: THE DEBATE OVER THE RIGHT TO RETRACT}

\section{OMRI BEN-SHAHAR}

I ended Contracts Without Consent: Exploring a New Basis for Contract Liability ${ }^{\prime}$ with a reminder that the analysis was "lacking in rigor and in nuance" and that "[i]t remains for future work to explore the extent to which the approach developed ... has the horsepower to resolve pragmatically the problems that have proven difficult for current doctrine and to examine whether these solutions advance the various social objectives associated with contract formation."

Such "future work" arrived sooner than I expected. I have now had the privilege to read the three commentaries that the University of Pennsylvania Law Review solicited, three razor-sharp critiques, producing precisely what I hoped would follow: an exploration, balanced with both theoretical nuance and empirical pragmatism, of the implications that flow from the no-retraction regime. And I may ultimately have to concede that much is still unresolved (or at least not convincingly resolved) by the proposed regime. But before we reembrace the traditional way of thinking about contracts, it may be worth our while to take a moment to understand the scope and the validity of the critiques and to determine whether a fine-tuned account of the noretraction regime emerges with the aid of such understanding.

The commentaries to Contracts Without Consent occupy a continuum between the curious and the angry. On the one hand, it is viewed charitably as an "intriguing" and "appealing new approach," embraced as a potential "new and promising beginning" of what can

${ }^{1}$ Omri Ben-Shahar, Contracts Without Consent: Exploring a New Basis for Contract Liability, 152 U. PA. L. REV. 1829 (2004).

Id. at 1872.

3 Id.

4 Daniel Markovits, The No-Retraction Principle and the Morality of Negotiations, $152 \mathrm{U}$.

PA. L. REv. 1903, 1903 (2004).

${ }^{5}$ Id.

${ }^{6}$ Id. at 1909. 
be called the law of negotiations (albeit a crude beginning). On the other hand, it is rejected as "conceptually confusing, practically impossible, and instrumentally unwise" - an "ultimately disastrous" liability regime. My purpose here, in the brief final words that the editors of the University of Pennsylvania Law Review have accorded me, is not to quiet the many tones of disagreement, but rather, to amplify them. I will try to use the commentators' own claims to show where the promise of my regime lies and to demonstrate how best to understand the weight of their critiques. Thus, in the next few paragraphs, I do not intend to respond to every difficulty identified by my critics, to show why they might be wrong (or perhaps right). Instead, I hope to highlight the main themes that all of the comments share and to briefly discuss what can be learned from these themes.

Many of the critiques of the no-retraction regime, when examined in isolation, seem powerful. But often, the very strength of one critique is based on premises that suggest a weakness of, or even a response to, another critique. Unlike in litigation, where a good attorney argues in the alternative-where what matters is that each argument has independent merit-here the mutual contradiction may undermine the appeal of the critics' bottom line.

Consider the following example. One major theme pursued by large sections of the critiques is that the no-retraction regime is so inconsistent with current practices of contracting that it would lead to "disastrous" outcomes or, at the very least, to ordinary opt-out. ${ }^{9}$ This argument-let us call it the "disaster argument"-suggests that a noretraction liability regime is at odds with existing practices to such an extent that it would cause people to change their negotiating practices in a dramatic and costly fashion. ${ }^{30}$ At the same time, another line of argument espoused by other sections of the critiques points out that the no-retraction regime is not such a revolutionary departure from current doctrine as it assigns liability in places where, by and large, it

${ }^{7}$ Jason Scott Johnston, Investment, Information, and Promissory Liability, 152 U. PA. L. REV. 1923, 1924 (2004).

${ }^{8}$ Id. at 1946.

${ }^{9}$ Id. at 1937-38; Ronald J. Mann, Contracts-Only with Consent, 152 U. PA. L. REV. 1873, 1879-86, 1896-901 (2004).

${ }^{10}$ Johnston, supra note 7, at 1923-24; Mann supra note 9, at 1898. 
already exists." This argument-let us call it the "redundancy argument"-suggests that the legal consequences of the no-retraction regime are often so similar to those of the current mutual assent regime that the difference between the two regimes is hardly detectable, and therefore, little value exists in replacing the traditional foundations with new, redundant ones.

While much can be said in support of each of these two critical arguments, it is striking that the disaster argument and the redundancy argument cannot both be valid at the same time. If the noretraction regime, by creating liability without consent, "turn[s] contract law upside down," as Jason Johnston fears, ${ }^{12}$ how could it be that parties are already regularly subject to liability so similar that "little can be gained by adopting this new regime?"13 If indeed disastrous, how could the no-retraction regime be "not substantially different from ... current law," ${ }^{14}$ which, all commentators agree, already provides "enormously powerful" liability prior to consent?"

More specifically, the critiques present the redundancy argument in two forms. One version of this argument examines existing doctrine and claims that it already gives rise to many of the legal implications of the no-retraction regime. Daniel Markovits, for example, observes that liability already arises "out of the broader negotiation relation," ${ }^{16}$ and that, as the case of Drennan v. Star Paving Co. ${ }^{17}$ implies, the law of contract has already "expressly welcomed" the principle that liability emerges prior to consent. ${ }^{18}$ Similarly, Johnston claims that in many important contexts in which there is no consent, promissory estoppel "has proven to be an enormously powerful tool for recovering damages." ${ }^{\prime 9}$ Ronald Mann likewise notes that the difference between the no-retraction regime and existing law is ambiguous and that recovery is already provided for under current law "in circumstances that do not involve a bargain," much the same as would occur under the proposed regime. ${ }^{20}$ To the extent that the commentators

"Johnston, supra note 7, at 1933-34; Mann, supra note 9, at 1874-75; Markovits, supra note 4 , at 1916-17.

\footnotetext{
${ }_{12}^{12}$ Johnston, supra note 7, at 1923.

13 Mann, supra note 9, at 1889.

${ }^{14}$ Id. at 1875.

15 Johnston, supra note 7, at 1933.

${ }_{16}$ Markovits, supra note 4, at 1917.

${ }^{17} 333$ P.2d 757 (Cal. 1958).

${ }^{18}$ Markovits, supra note 4, at 1917.

${ }^{19}$ Johnston, supra note 7, at 1933.

${ }^{20}$ Mann, supra note 9, at 1875.
} 
are correct in their assessment of existing law, the disaster argument appears somewhat overstated. While it might still be true that the proposed foundations for existing practices are misguided, the redundancy argument suggests that these new foundations are not likely to be so damaging.

The redundancy argument has another version, which compares the implications of the no-retraction regime, not to existing law, but instead, to existing negotiation practices. Highly methodical (as always) in pursuing this empirical perspective, Mann surveys actual contracting practices, particularly those utilized by parties entering complex agreements. He notes that the majority of negotiating parties regularly assume precontractual liability burdens, such as irrevocable offers, nonrefundable bonds and deposits, lockup fees, and other devices, all of which are intended to make retraction costly to themselves-in fact, no less costly than it would be under the no-retraction regime. $^{21}$ It is, of course, not clear that all transactors always desire such burdens; however, the prevalence and the pattern with which these private arrangements occur are, again, inconsistent with the claim that these burdens are "impossible" or "unwise."22 And Mann's account of the heightened prevalence of these private arrangements in complex transactions is hard to reconcile with the claim that parties to such transactions, who seek to acquire information throughout the negotiations, are the ones most likely to be chilled by the very similar liability burden of the no-retraction regime.

This contrast between the disaster and the redundancy arguments-between the claims that the no-retraction regime is dangerous and yet, at the same time, prevalent-is, of course, not a weakness of the critiques, but rather, their very strength. The critiques recognize the value of generality while understanding its danger. The value is in providing a unified understanding of, and a consistent structure to, various already existing contracting practices. The no-retraction regime was derived by induction, by inferring the hidden "formula" that explains actual law and practice-that which cannot be explained by the consensus-based assent theory. To be successful, this account must exhibit the redundancy characteristic; that is, it must closely resemble actual law and practice. The danger, on the other hand, and the need for caution is in the application of this formula beyond the circumstances that gave rise to it.

\footnotetext{
${ }^{21}$ Id. at 1889-91.

${ }^{22}$ Johnston, supra note 7, at 1924.
} 
In this spirit of caution, Markovits criticizes the absence of "adequate possibilities for exiting the negotiation relation." ${ }^{23}$ Slow, stale negotiations should be dissolved freely without the liability consequences that otherwise accompany a "betrayal" of the negotiations. Indeed, there is a lot of merit to this concern, and more work surely needs to be done in marking the precise boundaries of liability, both in entry (by defining what constitutes a "serious" proposal) and in exit (by distinguishing dissolutions from betrayal). Nevertheless, it is important to recall that under the no-retraction regime, unilateral exit from the negotiation does not automatically trigger retraction liability. In fact, the very same reasons that cause the negotiation to reach a deadlock-the insurmountable gaps between the parties, the lack of joint profitability, personal dislike, etc.-also suggest that it would be highly unlikely that either party would exercise the option that the regime grants her, to concede the deal that is most favorable to the other. And without such concession, no liability would arise. Thus, the more legitimate the reasons to exit from the negotiation, the less likely is dissolution to give rise to liability.

Another interesting inner tension in the critiques has to do with the precontractual reliance problem. Here, too, the critiques develop two themes that initially may seem difficult to reconcile. On the one hand, it is argued that liability in the precontractual phase would lead to excessive reliance and, hence, to excessive liability. This reading is based on the premise that parties have many occasions to incur unsolicited unilateral costs and might do so if only to make it costlier for their counterparts to break off negotiations. ${ }^{24}$ On the other hand, it is asserted that "preconsensual investments seem unnecessary in many cases" $^{25}$ and that the only meaningful kind of precontractual investment is in information. ${ }^{26}$ According to this line of reasoning, the "economists" concern with precontractual reliance is artificial. Of course, these claims - that there may be considerable opportunities to invest preconsensually and that precontractual reliance is of minor importance-do not have to be contradictory. Both claims may be correct, albeit in different contexts. Thus, even if Johnston is correct that Hoffman should not have relied on the negotiations with the Red

${ }^{23}$ Markovits, supra note 4, at 1918.

${ }^{24}$ See Johnston, supra note 7 , at 1937 (asserting that a no-retraction regime would induce "premature reliance expenses").

${ }^{25}$ Mann, supra note 9 , at 1881.

${ }^{26}$ Johnston, supra note 7 , at $1940-41$; Mann supra note 9 , at 1882-83. 
Owl Stores chain (which I doubt), ${ }^{27}$ it is clear from Mann's account of complex negotiations that there are still many instances in which precontractual reliance expenses (including investments in information) ought to be sunk.

The recognition that precontractual reliance is a potentially significant element of negotiations and that it should be protected and encouraged is at the core of many doctrines that have expanded liability to the precontractual stage, such as the Drennan decision, ${ }^{28}$ the Tribune duties, ${ }^{29}$ section 2-205 of the Uniform Commercial Code, ${ }^{30}$ and sections 45 and 87(2) of the Restatement (Second) of Contracts. ${ }^{31}$ Each one of these developments was accompanied by counterconcerns of excessive liability, i.e., fears that parties might be precluded from terminating negotiations or be forced into transactions. The noretraction principle, reflecting what Markovits labels a "freestanding morality of the negotiation relation," and fear. But I am not sure that the type of inefficient "intermeddling" that worries some-namely, excessive investments aimed at increasing liability-is a significant problem under this regime. For one, courts can usually distinguish between useful and wasteful reliance. $^{33}$ Moreover, there is no reason to think that any party would

${ }^{27}$ Johnston, supra note 7 , at 1939 \& n.59.

28 Drennan v. Star Paving Co., 333 P.2d 757 (Cal. 1958).

${ }^{29}$ Teachers Ins. \& Annuity Ass'n of Am. v. Tribune Co., 670 F. Supp. 491 (1987); see also Venture Assocs. v. Zenith Data Sys. Corp., 96 F.3d 275, 278 (7th Cir. 1996) ("[A complex negotiation] often is costly and time-consuming. The parties may want assurance that their investments ... will not be wiped out by the other party's footdragging or change of heart ....").

${ }^{30}$ U.C.C. $\$ 2-205$ (2003).

31 Restatement (SECOND) OF CONTRACTS $\$ 45$ (1981) (creating an option contract " $[w]$ here an offer invites an offeree to accept by rendering a performance and does not invite a promissory acceptance"); id. § 87(2) (allowing for an option contract to be formed in some circumstances where there has been reliance on an unaccepted offer).

${ }^{32}$ Markovits, supra note 4, at 1913.

33 Johnston, supra note 7, at 1938 \& n.55, refers to the case of GSGSB, Inc. v. New York Yankees, 862 F. Supp. 1160 (S.D.N.Y. 1994), aff'd, Nos. 95-9272, 96-9202, 1997 U.S. App. LEXIS 17433 (2d Cir. July 9, 1997), as an illustration of the problem of excessive and premature reliance. In that case, an architectural firm provided drawings before agreeing with the client on the fee and on the terms of its commission. Id. at 1162. The client eventually was denied a permit by the city and cancelled the project. Id. at 1163. The court found evidence that the expenditures by the firm were made without the expectation to be compensated, merely in the anticipation of securing a contract should the permit be granted. Id. at 1171. Thus, the court denied the claim for damages. Id. at 1178. If, indeed, as Johnston argues, this is a case of excessive, wasteful reliance, it is also a case that demonstrates how well courts can identify such premature 
benefit from such excessive reliance. Recall: For the relying party to impose liability on her counterpart, she must be willing to accept the terms that the counterpart required, supplemented by pro-defendant gap-fillers. Incurring high expenditures without a willingness to concede such terms would not be a profitable strategy. ${ }^{34}$

In the seams between disaster and redundancy, between overreliance and the disregarding of reliance altogether, the critiques identified areas in which the implications of no-retraction liability still need to be finely worked out. This Response is surely not the place to conduct such rigorous inquiry. This is not the place, for instance, to address the concern raised by all the critiques that under the noretraction regime any public invitation to bid, any request for quotes, could expose the solicitor to liability to each of the many respondents. ${ }^{35}$ If it were the proper place, I would have continued in the direction I began to articulate in the Essay, developing a richer analysis of when a decision to dissolve negotiations or to reject a bid is, and when it is not, a retraction of previous invitations. Such analysis is likely to succeed, I posited, if only because sensible bidders do not normally view a solicitor's non-acceptance of their bids as "retraction." ${ }^{36}$ Their expectations, when submitting their offers, are more modest, because the representations made to them are understood to include more subtle conditions and no guarantees. Thus, for example, a contracts professor who submits a manuscript to the University of Pennsylvania Law Review does not normally view its non-acceptance as "retraction," even though the Law Review invites submissions (unless, of course, the solicitation by the Law Review was made with an explicit assurance of publication). Because contracts professors know perfectly well how to distinguish between rejections and retractions when engaging in their private precontractual relations, there is every reason to expect that they will be able to enlist the same intuition and make similar distinctions when designing the law of precontractual relations.

Likewise, this is not the place to address another concern prominent in the critiques, namely, that parties who enter negotiations with

or excessive reliance. If anything, it reinforces the view that excessive reliance is not likely to occur.

${ }^{34}$ Indeed, in GSGSB, Inc., the architectural firm was unwilling to accept the deal as the client proposed it. $862 \mathrm{~F}$. Supp. at 1163 . Accordingly, under the no-retraction regime, the client would not be liable for the firm's investment.

${ }^{35}$ Johnston, supra note 7, at 1942-44; Mann, supra note 9, at 1879; Markovits, supra note 4 , at 1918-19.

${ }^{36}$ Ben-Shahar, supra note 1 , at 1867-68. 
genuine uncertainty about the quality of the "match" should be able to revise their positions in the course of negotiations as more information becomes available. Again, were it the proper place, I would have inquired into the efficiency and fairness of the traditional rule, which arbitrarily places all the risk of failed negotiations on the party who made the precontractual investment. A priori, it is not clear to me that, with the arrival of new information, the party who made a serious proposal that induced the investment should be completely free to revise her proposal or walk away without sharing the cost. Surely, had the negotiations succeeded, the retracting party would have benefited from the investment. Why, then, should she not bear some of the cost? More generally, it is certainly true that any redistribution of the cost of failed negotiations could have significant effects on how contracts are negotiated and how parties are matched. It might also have problematic effects on the cost and the ease with which negotiations can be dissolved. But it is far from clear that an extreme "freedom from contract" rule of no cost sharing and no liability prior to consent-of placing the loss where it arbitrarily lies-is the rule most likely to promote negotiations. The prevalence of precontractual costsharing agreements suggests otherwise.

If this were the place to further defend my idea of ascending liability, I would have argued that some of the views of the critics in fact support and complement, rather than weaken, the case for such gradual ascent. Johnston, for example, advocates that "early stage" statements should be viewed as "cheap talk," whereas "late stage" communications should give rise to liability. ${ }^{37}$ He suggests that the primary factor that distinguishes "early" from "late" stages and that gives rise to liability is the number of parties "on each side of the transactional divide." ${ }^{38}$ This number-of-recipients criterion is indeed a very sensible yardstick for measuring the seriousness of the proposal; however, like other measures of the intent to be bound, it too is a test that fulfills gradually. Between the starting point of "many" and the end point of "one," the number of parties with whom there is a chance to transact winnows down continuously throughout the negotiations. Thus, even under the Johnston yardstick for liability, there is no clear reason why liability should not emerge in a gradual fashion where the number of parties gradually diminishes.

\footnotetext{
${ }^{37}$ Johnston, supra note 7 , at $1943-45$

${ }^{38}$ Id. at 1944.
} 
The doctrine of mutual assent is the primary remnant of the longstanding dedication of contract law to the idea of mutuality: Unless both parties are equally bound, neither is bound. Many of the historical developments of contract law can be understood as absolving different aspects of mutuality. Thus, it was long ago thought that an agreement to buy cannot be binding before payment, or else only the seller would be bound, the buyer not having given anything. ${ }^{39}$ Until more recently, it was thought that an agreement that grants one party the power to determine the quantity is so one-sided that it could not be binding. ${ }^{40}$ Likewise, it was considered a verity that a promise to hold an offer open must be revocable, because as long as both parties are not bound, neither can be bound. ${ }^{41}$ These, and many other corollaries of the mutuality tradition, have been reformed, replaced by a jurisprudence more tolerant to one-sided contractual liability, more adequately tailored to reflect the varying tones and occasions of the parties' commitments. The no-retraction regime is a platform that tracks recent advances in this course of departure from mutuality and charts a tentative direction where it may be headed. (1987).

${ }^{39}$ A. W. B. Simpson, A History OF THE COMMON LAW OF CONTRACT 165-66

${ }^{40}$ Wickham \& Burton Coal Co. v. Farmers Lumber Co., 179 N.W. 417, 418-20 (Iowa 1920).

${ }^{41}$ Dickinson v. Dodds, 2 Ch. Div. 463, 469, 472-73 (Ch. App. 1876). 
$* * * * * * *$ 